\title{
GROWTH AND DISSOLUTION OF IRON AND MANGanese OXIDE FILMS
}

\author{
TECHNICAL REPORT \\ FOR GRANT NUMBER DE-FG02-03ER15384 \\ FOR THE PERIOD NOV 2007 TO DEC 2008 \\ SubMitTed To \\ DR. NiCHOLAS B. WOODWARD \\ OFFICE OF BASIC ENERGY SCIENCES \\ U.S. DEPARTMENT OF ENERGY \\ 19901 GERMANTOWN ROAD \\ GERMANTOWN, MARYLAND 20874-1290 \\ nick.woodward@science.doe.gov
}

PREPARED BY SCOT T. MARTIN

Gordon McKay PROFESSOR of ENVIRONMENTAL ChEMISTRY

DIVISION OF ENGINEERING AND APPLIED SCIENCES

HARVARD UNIVERSITY, CAMBRIDGE, MASSACHUSETTS 02138

scot_martin@harvard.edu

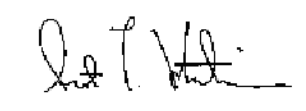

Scot T. Martin

22 Dec 2008

Date 


\section{Progress Report}

\section{Importance of Research Problem}

Growth and dissolution of $\mathrm{Fe}$ and $\mathrm{Mn}$ oxide films are key regulators of the fate and transport of heavy metals in the environment, especially during changing seasonal conditions of $\mathrm{pH}$ and dissolved oxygen. The $\mathrm{Fe}$ and $\mathrm{Mn}$ are present at much higher concentrations than the heavy metals, and, when Fe and Mn precipitate as oxide films, heavy metals surface adsorb or co-precipitate and are thus essentially immobilized. Conversely, when the $\mathrm{Fe}$ and $\mathrm{Mn}$ oxide films dissolve, the heavy metals are released to aqueous solution and are thus mobilized for transport. Therefore, understanding the dynamics and properties of $\mathrm{Fe}$ and $\mathrm{Mn}$ oxide films and thus on the uptake and release of heavy metals is critically important to any attempt to develop mechanistic, quantitative models of the fate, transport, and bioavailablity of heavy metals.

A primary capability developed in our earlier work was the ability to grow manganese oxide $\left(\mathrm{MnO}_{\mathrm{x}}\right)$ films on rhodochrosite $\left(\mathrm{MnCO}_{3}\right)$ substrate in presence of dissolved oxygen under mild alkaline conditions. The morphology of the films was characterized using contact-mode atomic force microscopy. The initial growth began by heteroepitaxial nucleation. The resulting films had maximum heights of 1.5 to $2 \mathrm{~nm}$ as a result of thermodynamic constraints. Over the three past years, we have investigated the effects of $\mathrm{MnO}_{\mathrm{x}}$ growth on the interactions of $\mathrm{MnCO}_{3}$ with charged ions and microorganisms, as regulated by the surface electrical properties of the mineral.

In 2006, we demonstrated that $\mathrm{MnO}_{\mathrm{x}}$ growth could induce interfacial repulsion and surface adhesion on the otherwise neutral $\mathrm{MnCO}_{3}$ substrate under environmental conditions. Using force-volume microscopy (FVM), we measured the interfacial and adhesive forces on a $\mathrm{MnOx} / \mathrm{MnCO}_{3}$ surface with a negatively charged silicon nitride tip in a $10-\mathrm{mM} \mathrm{NaNO}_{3}$ solution at $\mathrm{pH}$ 7.4. The interfacial force and surface adhesion of $\mathrm{MnO}_{\mathrm{x}}$ were approximately $40 \mathrm{pN}$ and $600 \mathrm{pN}$, respectively, whereas those of $\mathrm{MnCO}_{3}$ were essentially zero. The force differences between $\mathrm{MnO}_{\mathrm{x}}$ and $\mathrm{MnCO}_{3}$ suggest that oxide film growth can focus adsorbates to certain parts of the surface and thereby templating a heterogeneous layout of them. We suspected that the force differences were in part due to the differences in surface electrical properties.

In 2007, we investigated two important electrical properties of $\mathrm{MnO}_{\mathrm{x}}$ and $\mathrm{MnCO}_{3}$ surfaces, namely surface potential and ion mobility. Surface potential is a composite quantity that can be linked to the local lattice structure of the reconstructed surface and the adsorption of water layers. The mobile surface ions formed by dissolution can also contribute to surface potential. Using Kelvin probe force microscopy (KPFM) and scanning polarization force microscopy (SPFM), we found that $\mathrm{MnO}_{\mathrm{x}}$ possessed excess surface potentials of over $+200 \mathrm{mV}$ in humid nitrogen and the excess surface potential 
decreased with increasing relative humidity (i.e., increasing adsorbed water layers on the mineral surface). The dependence of the excess surface potential was attributed to the change of the contributions from mobile ions. These results supported our earlier hypothesis that $\mathrm{MnO}_{\mathrm{x}}$ and $\mathrm{MnCO}_{3}$ had different surface electrical properties.

In the third year, we systematically characterized that the change of the electrical double layer (EDL) structure of $\mathrm{MnCO}_{3}$ surface due to $\mathrm{MnO}_{\mathrm{x}}$ growth in aqueous solution and its dependence on $\mathrm{pH}$. The structure of the electrical double layer determines the electrostatic interactions between the mineral surface and charged adsorbates. As described by the Derjaguin-Landau-Verwey-Overbeek (DLVO) theory, the electrostatic force, together with van der Waals interaction, regulates surface adsorption and bacterial attachment. Once adsorbates establish contact with the surface, they must resist hydraulic shear forces through surface adhesion. The adhesion of mineral surfaces is also affected by their electrostatic interactions with adsorbates. To probe the EDL structure, we applied force-volume microscopy coupled with physical and chemical models of the SPM system.

\section{Work Performed and Our Findings}

Rhodochrosite surfaces of $(10 \overline{1} 4)$ orientation were prepared by cleavage (several millimeters thick and a few centimeters wide) of a large specimen using a razor blade in air. On these samples, $\mathrm{MnO}_{\mathrm{x}}$ films were grown in a teflon reactor, which was continuously fed by an oxygen-saturated sodium nitrate $\left(\mathrm{NaNO}_{3}\right)(10 \mathrm{mM})$ solution for three hours. The $\mathrm{pH}$ of the solution was adjusted to 6.3 by sodium hydroxide $(\mathrm{NaOH})$. After reaction, the sample was removed from the reactor, air-dried, and mounted on a steel puck with dental wax.

After film preparation, reacted surfaces were examined using contact- mode atomic force microscopy as well as force-volume microscopy from $\mathrm{pH} 5$ to 10 . The AFM and FVM measurements were performed using a Veeco multimode scanning probe microscope equipped with a NanoScope IIIa controller, a signal access module, a siliconnitride tip (Veeco NP-S), and a micro fluid cell (ca. $50 \mu \mathrm{L}$ ). The rhodochrosite sample was sealed by pressing the fluid cell on the steel puck with an o-ring. The fluid cell was then filled with experimental solution supplied by a syringe. The fluid cell and the sample were flushed with copious solution (>100 cell volumes) before any measurement. Imaging and FVM measurements were carried out in the presence of $1 \mathrm{mM} \mathrm{NaNO}_{3}$ solution, and the tip was fully immersed inside the sealed fluid cell. Measurements were conducted in two steps. In the first step, contact-mode microscopy was employed to locate a representative region of $1-\mu \mathrm{m}^{2}$ area that contained both oxide nanostructures and exposed rhodochrosite surface. In the next step, force-volume microscopy was performed over this region in a lateral matrix of $16 \times 16$ sampling locations, corresponding to 
$62.5 \times 62.5 \mathrm{~nm}^{2}$ per sampling point. The FVM measurements were performed after the experimental assembly had reached thermal equilibrium at $25( \pm 2)^{\circ} \mathrm{C}$. Post-measurement data processing followed standard operations, including plane-fitting, flattening, generating three-dimensional false-color images, and performing roughness analyses using WSxM (http://www.nanotec.es) and Igor Pro (WaveMetrics).

Force-volume measurements were made over the $\mathrm{MnO}_{\mathrm{x}} / \mathrm{MnCO}_{3}$ surface compared to the substrate to measure how the interfacial forces are changed by $\mathrm{MnO}_{\mathrm{x}}$ growth (Figures 1 to 3 ). For FVM measurements, the probe starts ca. $50 \mathrm{~nm}$ above the surface and gradually descends in steps of less than $0.25 \mathrm{~nm}$. The approach speed is less than 200 $\mathrm{nm} / \mathrm{s}$, ensuring both that the ionic atmosphere has sufficient time to equilibrate with the charged probe and that the hydrodynamic drag is negligible. At each step, the microscope records the vertical deflection of the probe cantilever by a laser beam shone on its back. The cantilever deflection $d$ is proportional to the interfacial force $\mathrm{f}$ by the cantilever spring constant $k$ (calibrated by the thermal-noise method), as follows: $f=k d$. Moreover, the distance $z$ between the tip and the surface can be calculated from $\mathrm{d}$. The basic information from FVM measurements is therefore a set of $256 f-z$ data pairs defining a force-distance curve at each sampling location. Figure 1 compares one force-distance curve over (a) $\mathrm{MnO}_{\mathrm{x}}$ to that over (b) $\mathrm{MnCO}_{3}$, and significant differences are apparent. Over the $\mathrm{MnO}_{\mathrm{x}}$, the interfacial force $f$ is attractive for surface-probe separations smaller than $2 \mathrm{~nm}$ but then becomes repulsive for greater separations. The interfacial forces are dominated by electrostatic repulsion and van der Waals attraction. Because the tip is not in contact with the surface during the approach, these differences arise from differing interfacial electrical forces between the probe (i.e., the tip) and the surface.

(a) $\mathrm{MnO}_{\mathrm{x}}$

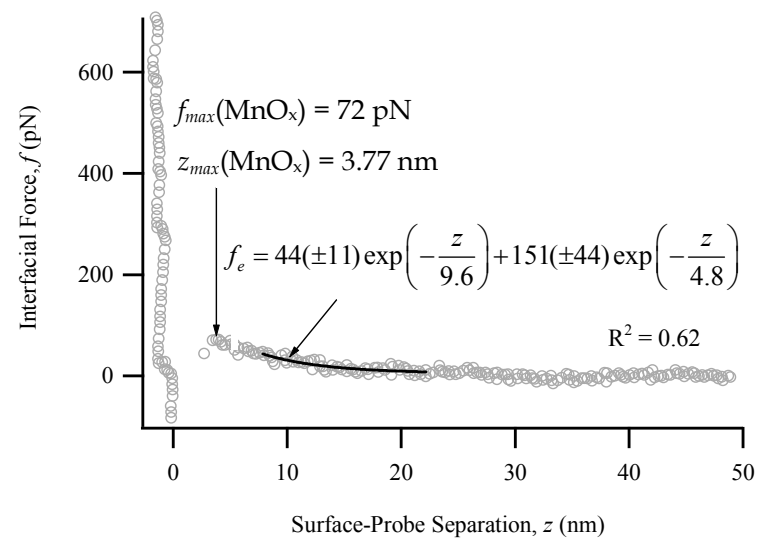

(b) $\mathrm{MnCO}_{3}$

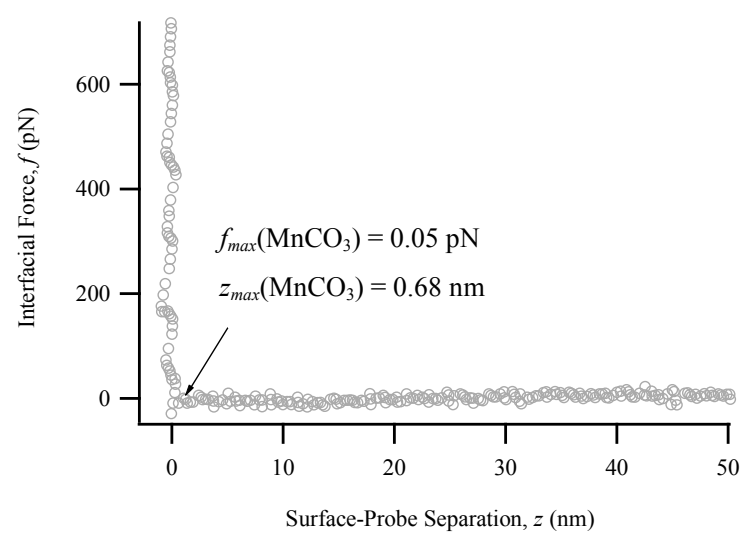

Figure 1. Representative force-distance curves obtained over (a) the oxide nanostructures and (b) the rhodochrosite substrate at $\mathrm{pH} 9.5$ in $1 \mathrm{mM} \mathrm{NaNO}_{3}$ solution. The solid curve represents a least-squares regression to the physical model of the electrostatic interaction between the tip and the surface. 
For presentation and further analysis and interpretation, we reduce the force-distance curve to a single data $\operatorname{pair} f_{\max }-z_{\max }$, i.e., the maximum observed repulsive force $f_{\max }$ and the associated distance $z_{\max }$ from the surface. In Figure 2, the color boundaries within the coarse-scale grids of $f_{\max }\left(\mathrm{MnO}_{\mathrm{x}}\right)$ shown in inset 2a-i and of $z_{\max }\left(\mathrm{MnO}_{\mathrm{x}}\right)$ shown in inset $2 c-i$ match well the finer-scale topography shown in inset $2 b-i$, therefore indicating that the growth of these nanostructures induces changes in the interfacial forces.

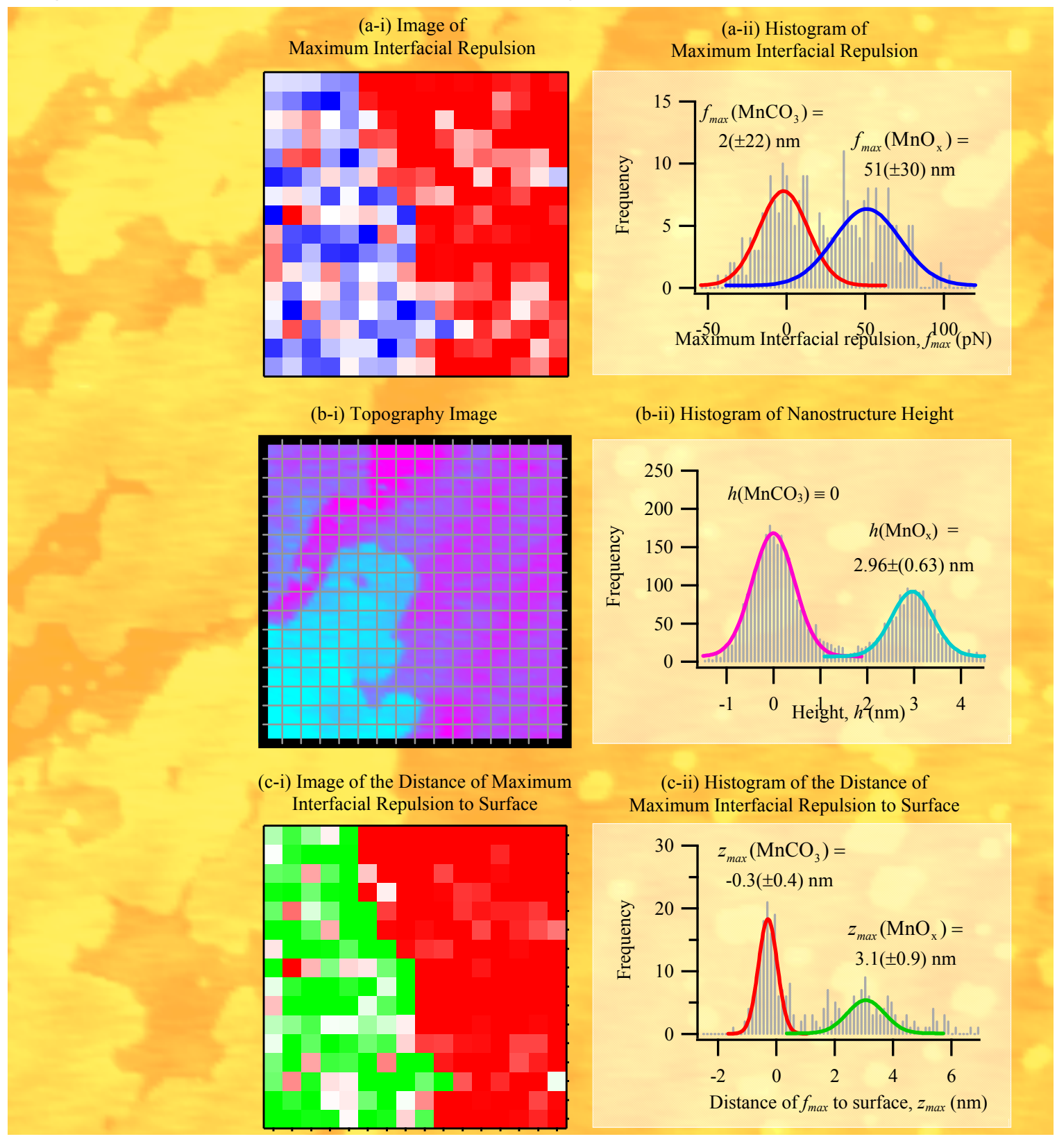

Figure 2. Topography is shown in image background. Inset panels show (a) the maximum interfacial repulsion fmax at each point in raster scan, (b) the corresponding topographic heights $h$, and (c) the distance of maximum interfacial repulsion to surface zmax. Conditions: reacted rhodochrosite surface in 1 $\mathrm{mM}$ NaNO3 solution at $\mathrm{pH} 9.5$. The background image shows the topography of a $4 \times 4-\mu \mathrm{m} 2$ area, in which oxide nanostructures are depicted in yellow against the orange rhodochrosite floor. The center of the topography image having a sampling area of $1 \times 1 \mu \mathrm{m} 2$ was selected for the force measurements. 
Figure 3 shows the $\mathrm{pH}$ dependence of $f_{\max }$ and therefore illustrates that these effects will be $\mathrm{pH}$ dependent, as explained by amphoteric $>\mathrm{MnOH}$ groups (where " $>$ " denotes surface) on the $\mathrm{MnOx}$ nanostructures. The presence of a strong electrostatic repulsive force over the oxide nanostructures in $1 \mathrm{mM} \mathrm{NaNO} 3$ solution at $\mathrm{pH} 9.5$ and the absence of it over the exposed substrate suggest that the nanostructures possess a high net charge. Specifically, $\sigma_{\text {nano }}=-0.0019( \pm 0.0005) \mathrm{C} \mathrm{m}^{-2}$ at $\mathrm{pH} 9.5$, corresponding to one negative elementary charge per $84( \pm 24) \mathrm{nm}^{2}$. In comparison, the substrate is either overall neutral or has at most a small charge.

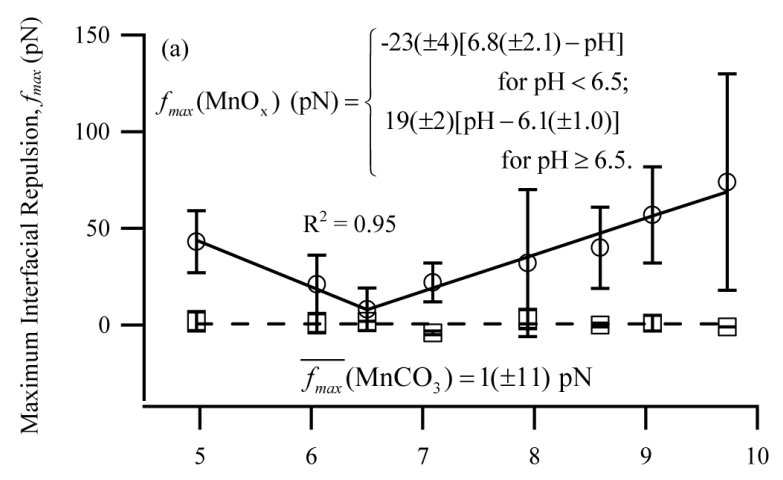

Figure 3. $\mathrm{pH}$ dependence of the maximum interfacial repulsion $f_{\max }$. The points represent the mode values of histogram distributions, such as those shown in Figure 2 for $\mathrm{pH}$ 9.5. The solid lines represent a piecewise linear regression of $f_{\max }\left(\mathrm{MnO}_{\mathrm{x}}\right)$. The horizontal dashed line shows the mean value of $f_{\max }\left(\mathrm{MnCO}_{3}\right)$.

On the basis of these differences in noncontact forces, a follow-on reasonable hypothesis is that $\mathrm{MnO}_{\mathrm{x}}$ growth may also have different contact, adhesive forces compared to the rhodochrosite substrate. Compared to interfacial repulsion, surface adhesion is the force required to pull the tip from the surface after contact. Figure 4 shows examples of the force on the cantilever as the AFM probe is retracted from $\mathrm{MnO}_{\mathrm{x}}$ surface (Figure 1a) and from the rhodochrosite substrate (Figure 1b). The cantilever presses with a force of $+1000 \mathrm{pN}$ when the measurement is started. The cantilever pressing force gradually decreases to zero and changes to a pulling force (i.e., $f<0$ ). For the oxide nanostructures, as the pulling force increases the tip of the probe finally escapes the attraction of the surface for $f=-500 \mathrm{pN}$, which gives the surface adhesion $f_{\text {adh }}=500$ $\mathrm{pN}$. In comparison, the surface adhesion on $\mathrm{MnCO}_{3}$ is essentially zero.

Figure 5 shows representative topography and adhesion images of a rhodochrosite surface having a $\mathrm{MnO}_{\mathrm{x}}$ film of ca. $0.9 \times 1.2 \mu \mathrm{m}^{2}$ for a $1 \times 1-\mu \mathrm{m}^{2}$ sampling area (resolution: $2 \times 2 \mathrm{~nm}^{2}$ ). In Figure 2a, the false colors show the film topography in cyan against the pink substrate. In Figure $2 b$, the image shows a map of surface adhesion $f_{\text {adh }}$ constructed from individual force-distance curves collected over the same region as Figure 1a. The adhesion image (resolution: $62.5 \times 62.5 \mathrm{~nm}^{2}$ ) is color-scaled according to the histograms in the lower panel. $\mathrm{MnO}_{\mathrm{x}}$ films are represented in green and blue and the 
substrate is in red. The difference between the $\mathrm{MnO}_{\mathrm{x}}$ regions colored in green and those in blue is that green represents $f_{\text {adh }}>0$ whereas blue represents $f_{\text {adh }}<0$. Negative values of $f_{\text {adh }}$ indicate that the probe cantilever experiences repulsion instead attractive adhesion from the nanostructures. This reversal from attraction to repulsion at a few nanostructure sampling locations is due to the domination of electrostatic repulsion over van der Waals attraction. Besides the regions in blue, most of $\mathrm{MnO}_{\mathrm{x}}$ film has surface adhesion greater than the rhodochrosite substrate as illustrated by the contrast between green and red. We obtain $f_{\text {adh }}\left(\mathrm{MnCO}_{3}\right)=-18( \pm 23) \mathrm{pN}$ and $f_{\text {adh }}\left(\mathrm{MnO}_{\mathrm{x}}\right)=10^{2.34( \pm 0.23)} \mathrm{pN}$ (mode: $219 \mathrm{pN}$ under a log-normal distribution emphasizing the multiplicative nature of its variance (34)) for the green region.

(a) $\mathrm{MnO}_{\mathrm{x}}$

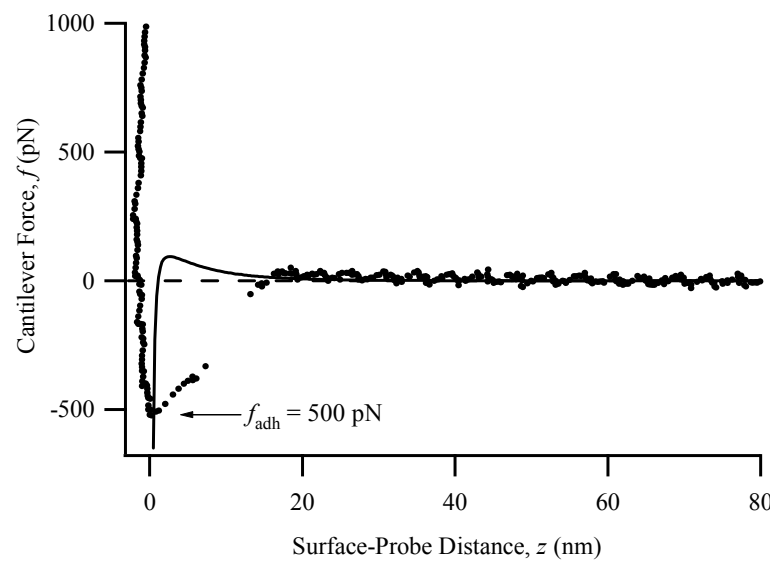

(b) $\mathrm{MnCO}_{3}$

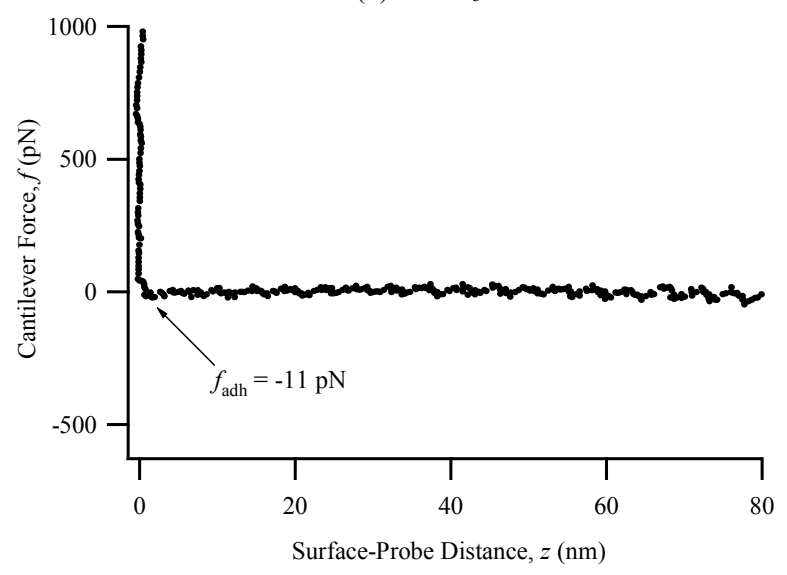

Figure 4. Adhesive forces. Shown on representative force-distance curves obtained while retracting the probe over (a) the $\mathrm{MnO}_{\mathrm{x}}$ film and (b) the rhodochrosite substrate in $1 \mathrm{mM} \mathrm{NaNO}_{3}$ solution at $\mathrm{pH}$ 8.6. The fluctuations for data around $f=0$ were due to building vibration. The continuous curve in (a) is the model result from the combination of electrostatic and van-der-Waals interactions.

(a) Topography

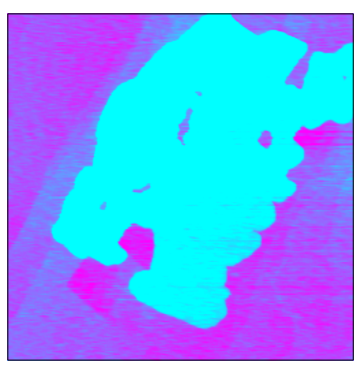

(b) Adhesion

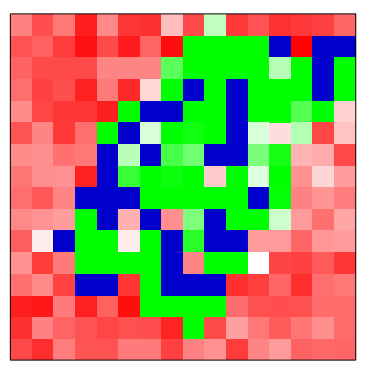

(c) Histogram of Adhesion

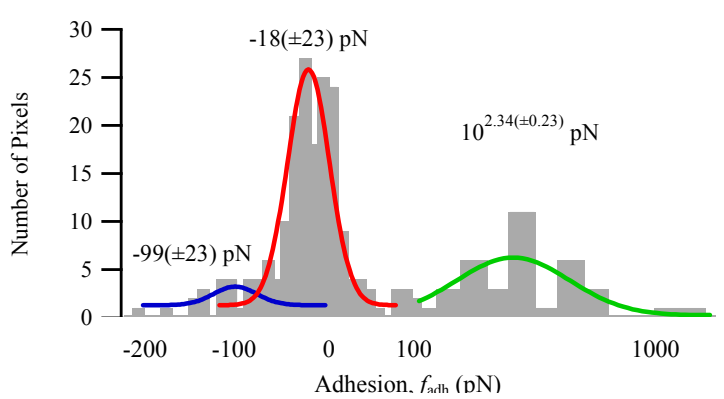

Figure 5. Images of (a) topography and (b) adhesion over $\mathrm{MnO}_{\mathrm{x}} / \mathrm{MnCO}_{3}$ surface in $1 \mathrm{mM} \mathrm{NaNO}$ solution at $\mathrm{pH}$ 6.0. Image size: $1 \times 1 \mu \mathrm{m}^{2}$. Color code: Cyan, green, and blue for the oxide nanostructure and pink and red for the exposed rhodochrosite substrate. The ordinate of surface adhesion has a mixed scale, which is linear under $100 \mathrm{pN}$ and exponential above, as shown in (c). The histogram of adhesion (c) is fitted into three Gaussian peaks marked by the same colors as the regions that they represent. $f_{\text {adh }}\left(\mathrm{MnCO}_{3}\right)$ is fitted to a normal distribution whereas $f_{\text {adh }}\left(\mathrm{MnO}_{\mathrm{x}}\right)$ is better represented by a log-normal distribution, which emphasizes the multiplicative nature of its variance. 
Figure 6 shows the $\mathrm{pH}$-dependence of surface adhesion $f_{\text {adh }}$ calculated from $f_{\text {pull,max }}$ over both the oxide nanostructures and the remaining rhodochrosite substrate. $f_{\text {adh }}\left(\mathrm{MnO}_{\mathrm{x}}\right)$ increases exponentially from $\mathrm{pH} 5.0$ to 7.1, reaches maximum, and then decreases from $\mathrm{pH} 7.1$ to 9.7 . The trend of $\log f_{\mathrm{adh}}\left(\mathrm{MnO}_{\mathrm{x}}\right) \mathrm{vs} \mathrm{pH}$ is described by a piecewise linear regression $\log f_{\text {adh }}\left(\mathrm{MnO}_{\mathrm{x}}\right)=0.29( \pm 0.10) \mathrm{pH}+0.64( \pm 0.63)$ for $\mathrm{pH}<7.1$ and $\log f_{\text {adh }}\left(\mathrm{MnO}_{\mathrm{x}}\right)=3.41( \pm 0.10)-0.10( \pm 0.08) \mathrm{pH}$ for $\mathrm{pH} \geq 7.1$. In contrast to $f_{\text {adh }}\left(\mathrm{MnO}_{\mathrm{x}}\right)$, the regression of $f_{\text {adh }}\left(\mathrm{MnCO}_{3}\right)$ with $\mathrm{pH}$ is not statistically significant, indicating no detectable dependence on $\mathrm{pH}$.

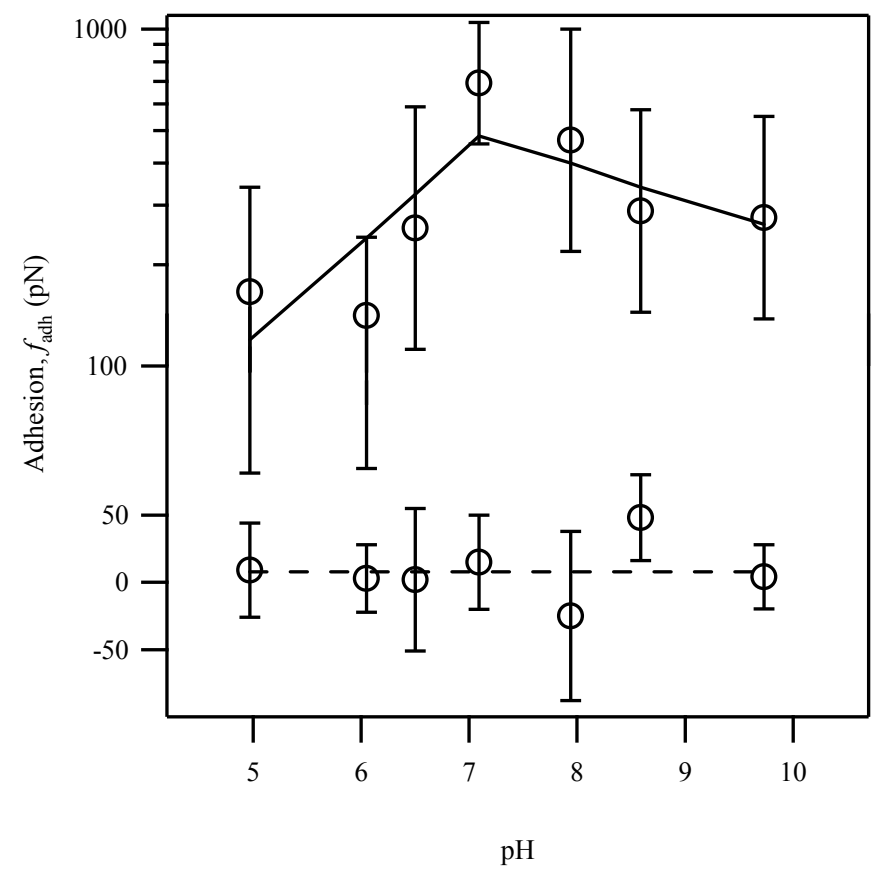

Figure 6. Changes of surface adhesion with $\mathrm{pH}$ in $1 \mathrm{mM} \mathrm{NaNO}_{3}$ solution. The black line is a least-square stepwise linear regression of the nanostructure surface adhesion. The dashed line is the average of the rhodochrosite surface adhesion. The regression equation and the average value are provided in the text. The ordinate of $f_{\text {adh }}$ is a mixed linear-exponential scale as the same as in Figure 5.

The dependence of $f_{\max }\left(\mathrm{MnO}_{\mathrm{x}}\right)$ and fadh $\left(\mathrm{MnO}_{\mathrm{x}}\right)$ on $\mathrm{pH}$ (Figures 3 and 6) suggests that the $\mathrm{MnO}_{\mathrm{x}}$ surface and that of the silicon-nitride probe have similar points of zero charge $\left(\mathrm{pH}_{\mathrm{pzc}}\right)$, specifically around 6 to 7 . We prove this argument based on the $f_{\max }\left(\mathrm{MnO}_{\mathrm{x}}\right)-\mathrm{pH}$ relationship as follows. The charges on $\mathrm{MnO}_{\mathrm{x}}$ and the probe must both reverse from being negative to being positive at approximately similar $\mathrm{pH}$ because $f_{\max }\left(\mathrm{MnO}_{\mathrm{x}}\right)$ is repulsive at both $\mathrm{pH}<6.5$ and $\mathrm{pH}>6.5$. Otherwise, an electrostatic attraction (i.e., $\left.f_{\max }\left(\mathrm{MnO}_{\mathrm{x}}\right)<0\right)$, which was not observed, would have been measured for $\mathrm{pH}$ values between $\mathrm{pH}_{\mathrm{pzc}}$ (probe) and $\mathrm{pH}_{\mathrm{pzc}}\left(\mathrm{MnO}_{\mathrm{x}}\right)$ because over this range the $\mathrm{MnO}_{\mathrm{x}}$ surface and the probe would have been oppositely charged. Similarly argument can be made based on the $f_{\text {adh }}\left(\mathrm{MnO}_{\mathrm{x}}\right)-\mathrm{pH}$ relationship. The charge reversal around $\mathrm{pH}_{\mathrm{pzc}}\left(\mathrm{MnO}_{\mathrm{x}}\right)$ on $\mathrm{MnO}_{\mathrm{x}}$ surface can be explained by a proton-hydroxide charging mechanism similar to iron oxides: 


$$
\begin{aligned}
& >\mathrm{MnO}_{\mathrm{x}} \mathrm{H}^{+} \stackrel{K_{1}}{\rightleftarrows}>\mathrm{MnO}_{\mathrm{x}}+\mathrm{H}^{+} \\
& >\mathrm{MnO}_{\mathrm{x}}+\mathrm{H}_{2} \mathrm{O} \stackrel{K_{2}}{\rightleftarrows}>\mathrm{MnO}_{\mathrm{x}} \mathrm{OH}^{-}+\mathrm{H}^{+}
\end{aligned}
$$

where $K_{1}$ and $K_{2}$ are equilibrium constants and $\mathrm{pH}_{\mathrm{pzc}}\left(\mathrm{MnO}_{\mathrm{x}}\right)=\left(\mathrm{p} K_{1}+\mathrm{p} K_{2}\right) / 2$.

We estimate with $95 \%$ confidence that $\mathrm{pH}_{\mathrm{pzc}}$ (probe) and $\mathrm{pH}_{\mathrm{pzc}}\left(\mathrm{MnO}_{\mathrm{x}}\right)$ lie between $5.9( \pm 2.1)$ to $7.2( \pm 1.0)$ based on twice the uncertainty of force measurements, as estimated using data for $z>40 \mathrm{~nm}$. The estimated $\mathrm{pH}_{\mathrm{zpc}}$ values overlap with $\mathrm{pH}_{\mathrm{pzc}}$ (probe) between 4.5 and 7.2 reported in the literature (Taboada-Serrano et al., 2005, Environ. Sci. Technol., 39, 6352-6360; Senden et al., 1994, Langmuir, 10, 358-362; Raiteri et al., 1998, Sens. Actuator B-Chem., 46, 126-132, and Arai et al., 1996, Thin Solid Films, 273, 322-

326) as well as several bulk manganese oxides, such as $\mathrm{pH}_{\mathrm{pzc}}\left(\mathrm{MnO}_{2}\right)$ between 5.3 and 7.7 and $\mathrm{pH}_{\mathrm{pzc}}(\mathrm{MnOOH})$ between 6.2 and 8.5 (Kosmulski, 2002, J. Colloid Interface Sci., 253, 77-87; Kosmulski, 2004, J. Colloid Interface Sci., 275, 214-224; and Kosmulski, 2006, J. Colloid Interface Sci., 298, 730-741). The estimate of $\mathrm{pH}_{\mathrm{pzc}}\left(\mathrm{MnO}_{\mathrm{x}}\right)$ differs significantly, however, from $\mathrm{pH}_{\mathrm{pzc}}\left(\mathrm{Mn}_{3} \mathrm{O}_{4}\right)>10$ and $\mathrm{pH}_{\mathrm{pzc}}\left(\mathrm{MnO}_{1.88}\right)<2.4$. The proposed $\mathrm{pH}_{\mathrm{pzc}}\left(\mathrm{MnO}_{\mathrm{x}}\right)$ of between 6 to 7 for the grown nanostructures, which may have properties different from bulk materials, is nonetheless reasonable compared to the values of at least some bulk manganese oxide materials.

The measurements show that the surface charge of exposed rhodochrosite is effectively indistinguishable from neutral across $\mathrm{pH} 5.0$ to 9.5 in our experimental system. For comparison, regarding surface charge density, Van Cappellen et al. (Geochim. Cosmochim. Acta, 1993, 57, 3505-3518) interpreted the acid-base titration experiment of Charlet et al. (Geochim. Cosmochim. Acta, 1990, 54, 2329-2336) using a

surface complexation model for the species $>\mathrm{CO}_{3} \mathrm{H}^{0}$ and $>\mathrm{MnOH}^{0}$. Using the equilibrium constants obtained by these authors and the Graham equation suitable for our lowpotential condition, we estimate a surface charge for rhodochrosite of $\sigma_{s u b}=-0.00043$ $\mathrm{C} / \mathrm{m}^{2}$ at $\mathrm{pH} 9.5$ and $1 \mathrm{mM}$ ionic strength. This value, which is an order of magnitude smaller than $\sigma_{\text {nano }}$, agrees qualitatively with our experimental observation that the surface charge of the rhodochrosite is much less than that of the $\mathrm{MnO}_{\mathrm{x}}$ film.

\section{Broader Implications of Our Findings}

The repulsive interfacial force induced by $\mathrm{MnO}_{\mathrm{x}}$ films at distances greater than $2.4( \pm 1.1) \mathrm{nm}$ creates an energy barrier for similarly charged adsorbates to approach the surface. By integrating the force-distance curve shown in Figure 1a, we estimate that the energy barrier is $6.2 \times 10^{-19} \mathrm{~J}$ at $\mathrm{pH} 9.5$ for a colloidal particle or a bacterial cell to approach the surface, under the assumption that the SPM probe qualifies as an acceptable surrogate for them. If the adsorbate is a spherical colloidal particle and settles under 
gravity, the diameter of the colloidal particle must exceed $3.4 \mu \mathrm{m}$ to overcome this barrier with its inertia, according to the Stokes' law. For a bacterial cell having swimming motility, a minimum speed of $17 \mathrm{~mm} / \mathrm{s}$ is required to glide through the barrier under the assumption that its inertia equals its kinetic energy. Bacteria such as vibrio cholerae and pseudomonas aeruginosa, however, swim with a speed less than $100 \mu \mathrm{m} / \mathrm{s}$. Conversely, charged species in solution having an opposite charge to the nanostructures (i.e., unlike the SPM probe) will be attracted to the surface. Unlike these regions of the surface having oxide nanostructures, the attraction or repulsion is absent over parts of the surface representing remaining exposed rhodochrosite, implying that certain adsorbates will be favorably directed to some parts of the surface rather than others. The net result is a mechanism for focusing adsorbates to certain parts of the surface and thereby templating a heterogeneous layout of them.

The interfacial-force heterogeneity demonstrated herein for oxide nanostructures grown on rhodochrosite is more generally applicable to other chemical systems. For example, Taboada-Serrano et al. (2005) showed that the adsorption of copper cations also creates force heterogeneity on silica surfaces. In applications directed to the natural environment accounting for surface heterogeneity will be complex but important when processes such as contaminant immobilization or bacterial attachment are the focus.

The largely attractive surface adhesion of $\mathrm{MnO}_{\mathrm{x}}$ films creates an energy barrier to help attached adsorbates resist hydraulic shear. $f_{\text {adh }}\left(\mathrm{MnO}_{\mathrm{x}}\right)$ ranges from $141-685 \mathrm{pN}$ for an adsorbate similar to the SPM tip in the tested $\mathrm{pH}$ range. To overcome such an adhesion by shear friction, flow or turbulence must provide a velocity $v$ greater than $0.7-$ $3.6 \mathrm{~m} / \mathrm{s}$ based on the Stock's law $f_{\mathrm{f}}=6 \pi \eta R v$ and water viscosity $\eta=10^{-3} \mathrm{~Pa} \cdot \mathrm{s}$. This velocity is much greater than the typical water of several meters per day velocity in subsurface aquifers or the velocity of several meters per hour in filter beds for water and wastewater treatment. Hence, the presence of $\mathrm{MnO}_{\mathrm{x}}$ films will lead to the irreversible adsorption of certain adsorbates that would have been reversibly adsorbed on the bare rhodochrosite surface.

Attractive surface adhesion can be reversed to repulsion due to surface roughness. The roughness of an adsorbent surface is especially important when the adsorbates such as nanomaterials or nanoparticles have small sizes. Like the sharp AFM tip used in this study, these small adsorbates may experience either attraction or repulsion at the proximity of contact depending on where they land on the adsorbate surface.

Although we have presented our results of interfacial forces and surface adhesion separately to focus on each topic at a time, the two sets of data can be obtained by a single FVM experiment. In such an experiment, an interfacial force-distance curve is first 
collected by ascending the sample stage from a position where the mineral surface is ca. $50-100 \mathrm{~nm}$ far away from the probe tip. After the tip establishes firm contact with the mineral surface, the sample stage descends to collect an adhesion force-distance curve. Once both curves are measured, the probe is moved to the next $x-y$ coordinate to survey the surface in the raster fashion.

Force-volume microscopy has been applied to the studies of the interfacial and surface forces on clean surfaces of various minerals, including mica, silica, and metal oxides as well as on organic surfaces. To our knowledge, however, it has not been applied to map the interfacial and surface forces of environmentally relevant nanostructures grown on mineral surfaces to understand contaminant fate and transport. The findings supported in this grant, by developing mechanistic understanding, are leading to improved accuracy in models of contaminant fate and transport. 
2. Statement of Unexpended Funds at the End of the Budget Period

\section{Statement of Unexpended Funds}

DOE Award No: DE-FG02-03ER15384

\begin{tabular}{|c|c|c|c|}
\hline & & $\begin{array}{c}\text { Actual } \\
\text { Expenses }\end{array}$ & $\begin{array}{l}\text { Projected } \\
\text { Expenses }\end{array}$ \\
\hline Budget Categories & $\begin{array}{c}\text { Yr } 3 \\
\text { BUDGET }\end{array}$ & $\begin{array}{c}9 / 1 / 07- \\
11 / 26 / 08\end{array}$ & $\begin{array}{c}\text { Through } \\
1 / 31 / 09\end{array}$ \\
\hline
\end{tabular}

PERSONNEL
A. PI Salary
$\$ 16,248 \quad \$ 17,000$
B. Other Personnel
$\$ 32,868 \quad \$ 40,800$

Fringe Benefits (PI and Other Personnel)

TOTAL SALARY \& FRINGE

\begin{tabular}{rrr}
$\$ 3,932$ & $\$ 13,519$ & \\
\hline$\$ 53,048$ & $\$ 71,319$ & $\$ 0$
\end{tabular}

SUPPLIES

$\$ 7,000 \quad \$ 2,305$

DOMESTIC TRAVEL

$\$ 1,500 \quad \$ 2,473$

PUBLISHING

$\$ 750$

TOTAL DIRECT COSTS

\begin{tabular}{rrr}
\hline$\$ 62,298$ & $\$ 76,097$ & $\$ 0$ \\
$\$ 39,871$ & $\$ 48,702$ & \\
\hline$\$ 102,169$ & $\$ 124,799$ & $\$ 0$
\end{tabular}

Projected Remaining Balance as of 11/26/08: $\$ 91$ 


\section{List of Publications Resulting from the Grant}

1. C. Na and S.T. Martin, "Manganese Oxide Nanostructure Grown on Manganese Carbonate Alter the Layout of Adhesive Forces," near submission.

2. C. Na, C.J. McNamara, N.R. Konkol, K.A. Bearce, R. Mitchell, and S.T. Martin, "Physicochemical origins of bacterial attachment examined by force-volume microscopy," submitted.

3. Na C.Z. and Martin S.T., "Interfacial forces are modified by the growth of surface nanostructures" Environmental Science \& Technology, 2008, 42, 6883-6889.

4. Kendall T.A., Na C.Z., Jun, Y.S., and Martin S.T., "Electrical properties of mineral surfaces for increasing water sorption" Langmuir, 2008, 24, 2519-2524.

5. Na, C.Z., Kendall, T.A., and Martin, S.T., "Surface-potential heterogeneity of reacted calcite and rhodochrosite," Environmental Science \& Technology, 2007, 41, 64916497.

6. Kendall, T.A. and Martin, S.T., "Water-Induced Reconstruction that Affects Mobile Ions on the Surface of Calcite," Journal of Physical Chemistry A, 2007, 111, 505-514.

7. Jun, Y.S., S.K. Ghose, T.P. Trainor, P.J. Eng, and S.T. Martin, "Structure of the Hydrated (10-14) Surface of Rhodochrosite $\left(\mathrm{MnCO}_{3}\right)$," Environmental Science and Technology, 2007, 41, 3918-3925. 